Pamiętnik Literacki 2015, 3, s. 171-193
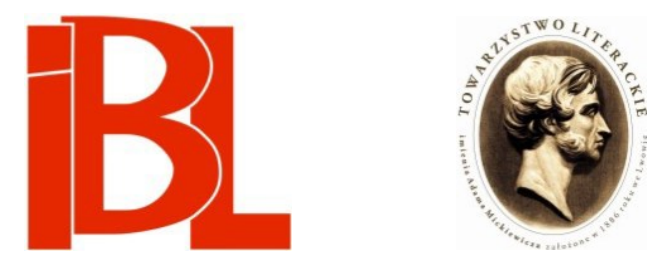

\title{
Dykcja milcząca: Celan i Webern
}

\author{
Michalina Kmiecik
}




\section{Z A G A D N I N I A J E Z Y K A A R T Y T T C Z N E G O}

Pamiętnik Literacki CVI, 2015, z. 3, PL ISSN 0031-0514

MICHALINA KMIECIK Uniwersytet Jagielloński, Kraków

\section{DYKCJA MILCZACA: CELAN I WEBERN}

Awangardowa estetyka negatywna skupia się wokół tego, czego nie ma. Owym miejscem pustym dzieła sztuki jest zaś przede wszystkim milczenie: brak dźwięku, słowa, koloru czy kształtu. Znak wprowadza odbiorce w świat znaczenia, budowania sensu, który - nawet jeśli wydaje się nieprzejrzysty lub ukryty - może zostać poddany procesom interpretacji. Milczenie stanowi $z$ kolei rewers znaku, jego negatywne odbicie, i wymaga innego rodzaju lektury. Jak stwierdza Theodor W. Adorno w Teorii estetycznej, ciemność dzieła sztuki posługującego się „milczącą mową” nie powinna być substytuowana jasnością sensu ${ }^{1}$ : wszelkie próby spójnego i całościowego wytłumaczenia nieuchronnie przeczą wewnętrznej prawdzie (a także strukturze) utworu. Czytelnik znajduje się więc $\mathrm{w}$ przestrzeni niezrozumienia i tylko akceptacja „rozbitego sensu”, którego nie sposób ponownie scalić, pozwala mu na obcowanie z przedmiotem estetycznym. Artyści tacy jak Paul Celan czy Anton Webern z pewnością wpisują się w Adornowską wizję nowoczesnej s z tuki bezmownej:

Prawdziwa mowa sztuki jest bezmowna, jej bezmowny moment $\mathrm{w}$ tym przewyższa sygnifikatywny moment poezji, że nie brakuje go również w muzyce. Podobieństwo waz [etruskich] do mowy jest najbliższe jakiemuś „oto jestem” bądź ,jestem tym”, styka się z takim byciem sobą, którego z interdependencji istnienia nie wydobywa dopiero identyfikujące myślenie. [...] Linijka wiersza Rilkego „denn da ist keine Stelle / die dich nicht sieht” (,i nie ma takiego miejsca / które by na ciebie nie patrzyło”) [...] skodyfikowała w niemal nieprześcigniony sposób ową niesygnifikatywną mowę dzieł sztuki: wyraz jest spojrzeniem dzieł sztuki. Ich mowa jest jednak w stosunku do języka sygnifikatywnego czymś starszym, ale nie spełnionym: jak gdyby dzieła sztuki, upodobniając się do podmiotu swoją spójnością, powtarzały to, w jaki sposób on się poczyna i wyłania. Wyraz mają one nie tam, gdzie przekazują podmiot, ale tam, gdzie drżą prehistorią podmiotowości, prehistorią uduchowienia [... $]^{2}$.

Niemiecki filozof charakteryzuje „bezmowność” jako prawdziwy język dzieła sztuki, które ujawnia swoją tajemnicę pozaznakowo - dopiero w ciszy, pauzie, pustym miejscu między wersami udaje się dostrzec jej iskrę. Adorno podkreśla jednak, iż jest ona „niesygnifikatywna”, nie prowadzi do odszyfrowania sensu utworu. Właśnie moment braku konkretnego znaczenia, puste „to oto” ${ }^{3}$ staje się dla estetyka chwila negatywnej epifanii tekstu, w której nie dochodzi do przyswojenia go

Th. W. Ad or n o, Teoria estetyczna. Przeł. K. Krzemi eniowa. Warszawa 1994, s. 207.

Ibidem, s. 207.

Ibidem, s. 39. 
jako całości, lecz do przyjęcia jego ciemności. Pytające spojrzenie artefaktu, jego głębokie milczenie każe stale na nowo podejmować wysiłek czytania - takiego wszakże, które nie będzie dążyło do łatwej eksplikacji, ale będzie zstępowaniem w mrok. Tajemnica dzieła musi pozostać nierozszyfrowana, ponieważ „im łatwiej rozwiązuje ono swoją zagadkę w jakimś jednym wymiarze, [...] tym mniej wyjaśnia ze swej konstytutywnej zagadkowości”" . Udzielenie odpowiedzi na stawiane przez nie pytania prowadzi więc do wciąż nowych wątpliwości - lektura zmienia się tym samym w niekończący się ciag podejrzeń: wobec tekstu, twórcy, a przede wszystkim wobec samego czytelnika i jego własnych możliwości poznawczych.

Istnienie struktur milczących w dziełach artystycznych przysparza wielu problemów badaczom sztuki. Jak opisać tego rodzaju aktywność? Czy istnieją tradycyjne kategorie, które pomagaja uchwycić poszczególne strategie? Przydatne wydaje sie pojęcie retoryki milczenia, do jakiego na polskim gruncie odwołuje się Piotr Śniedziewski w książce Mallarmé - Norwid. Milczenie i poetycki modernizm we Francji oraz $w$ Polsce ${ }^{5}$. Badacz wyróżnia trzy sposoby manifestowania się milczenia w dziele: tematyzację, „pismo milczenia” oraz „retorykę milczenia”. Z mojego punktu widzenia interesujące sa ostatnie dwa. Pierwszy z nich polega według Śniedziewskiego na stworzeniu nowego języka poetyckiego, odrzucającego jasną konotację, a także eliminującego wszelkie odniesienia do „języka codziennego, błahego i zużytego"6. Co ważne, dzięki refleksji nad „pismem milczenia” liryka pogłębia swoją samoświadomość i koncentruje się na strukturze milczącej jako podstawowym wyznaczniku wiersza ${ }^{7}$. Osiagnięciu tego efektu ma służyć idea wiersza nieprzechodniego u Stéphane’a Mallarmégo czy Cypriana Norwida ${ }^{8}$. Retoryka milczenia opiera się na tak rozumianym dziele; charakteryzuje się jednak wprowadzeniem konkretnych figur sygnalizujących milczenie (zakorzenionych $\mathrm{w}$ tradycji retorycznej). Śniedziewski, próbując sformułować pozytywną definicję retoryki milczenia, wylicza następujące wyznaczniki: dowartościowanie autotelicznej funkcji języka, nieprzechodni charakter tekstu, negacja mimesis, brak dawnego dyskursu i podmiotu lirycznego, występowanie tropów milczenia (takich jak elipsa, afereza) oraz figur zbudowanych na zasadzie przemilczenia (np. metafora lub symbol), dekompozycja języka czy układu typograficznego ${ }^{9}$. Definicja ta dotyczy

4 Ibidem, s. 223.

5 P. Śni e dzi e w s ki, Mallarmé - Norwid. Milczenie i poetycki modernizm we Francji oraz $w$ Polsce. Poznań 2008. Analogiczną kategorię do opisania twórczości Celana wybiera A. J. A. Mi ch a el w monografii Paul Celan: A Rhetoric of Silence (London 1987 /praca dostępna w British Library w bazie EThOS na stronie: http://ethos.bl.uk; dostęp 15 VII 2015〉). U tego badacza kategoria owa nie jest jednak tak mocno związana z tradycją retoryczną jak u Śniedziewskiego. Michael traktuje ją bardzo metaforycznie, a jako główne „tropy milczenia” wskazuje brak zakończenia (unfinality), rozłączność (disjunction), rozumianą jako sprzeczność lub paradoks, oraz przesunięcie znaczenia (displacement).

$6 \quad$ Śniedziewski, op. cit., s. 19.

7 Śniedziewski (ibidem) pisze: „Pamiętać bowiem trzeba o pracy poetów nad struktura poezji, nad jej poziomem fonicznym, syntaktycznym i semantycznym”.

8 Wiersz nieprzechodni według Śn i e d zi e w s k i e go (ibidem, s. 11) „nie potrzebuje [...] już żadnego, zewnętrznego wobec niego, uzasadnienia. Jest jednocześnie wolny od mimesis (jego zadaniem nie jest imitowanie rzeczywistości) i niczego nie zawdzięcza innym rodzajom ludzkiej aktywności [...]”. Ibidem, s. 88-89. 
więc, $z$ jednej strony, makrostruktur (postaci tekstu i jego wizualnego rozmieszczenia), z drugiej zaś - planu szczegółowego (konkretnych tropów retorycznych, interpunkcji).

Czym zatem retoryka milczenia różni się od proponowanej przeze mnie dykcji milczącej? Odpowiedź nie jest prosta, ponieważ oba pojęcia w wielu miejscach pokrywają się i próbują wyjaśnić analogiczne zjawiska artystyczne. Śniedziewski poszukuje jednak przede wszystkim struktur znanych $z$ tradycji, śledzi zmiany, jakie w nich zachodzą w obrębie modernizmu, pokazuje, jak retoryka może funkcjonować w dziele nowoczesnym oraz jakim ulega przekształceniom. Badacz opisuje tekst literacki przy użyciu wypracowanych już kategorii poetologicznych (u Mallarmégo i Norwida szuka aliteracji, suspensji, zeugmy czy hyperbatonu) i uzupełnia swoje analizy przedstawieniem struktur właściwych liryce wczesnomodernistycznej (przeobrażeń typograficznych czy wynikających $z$ autonomizacji dzieła sztuki) ${ }^{10}$. Mówiąc o dykcji milczącej, odchodzę od takiej metody: skupiam się raczej na strategiach nietradycyjnych, występujących w awangardowych i poawangardowych poetykach eksperymentalnych. Próbuję nadać tym strategiom nazwy i scharakteryzować ich własności - pokazujacc zarazem ich pojedynczość, niesystemowość, niechęć do dopasowania się do określonego modelu pisarstwa. Retoryka Śniedziewskiego stanowi więc idealne narzędzie do analizy dzieł wczesnomodernistycznych, które nie wyzwoliły się jeszcze spod wpływu dawnej retoryki. Dykcja milcząca to ujęcie radykalniejsze, odnosi się przede wszystkim do praktyk awangardowych oraz późnomodernistycznych, wymykających się obowiązującym klasyfikacjom i wymagajacych stworzenia nowych środków ich opisu. O ile u Mallarmégo odnajdujemy tropy stylistyczne i retoryczne uświęcone przez tradycję, o tyle u Celana sa one stopniowo wypierane przez struktury skrajniejsze estetycznie: rozbijanie i zanikanie słów, koncentrację na pojedynczej, zautonomizowanej literze, zanik składni, znoszenie się sensów. Obok środków znanych i występujących w poezji od wieków (nie zapominajmy, że u Celana także napotkamy klasyczne pytania retoryczne czy reticentię) mnożą się inne strategie, które sprawiają, że zaczynamy mówić nie o przemilczeniu w dziele, ale o jego milczeniu. Ta zmiana zaś stanowi o rozwoju poetyki i estetyki, a przede wszystkim wskazuje na przełom doświadczenia: doprowadzone do skrajności odczucie kryzysu i rozbicia świata (wzmacniane przez kolejne wydarzenia historyczne - wojny światowe, piekło Szoa) wiedzie w rezultacie do wytworzenia się nowej dykcji (nie kończąc się jedynie na użyciu pewnych technik retorycznych). Proponowana przeze mnie formuła jest więc nie tylko próba wypracowania kategorii teoretycznej, która pozwoli czytać sztukę awangardy, ale także diagnozą stanu języka artystycznego (zarówno poetyckiego, muzycznego, jak i wizualnego) właściwego już dla sztuki lat trzydziestych ubiegłego stulecia.

Najbardziej radykalne, moim zdaniem, postacie owego języka - liryka Celanowska oraz Webernowska dodekafonia ${ }^{11}$ - pozwolą najlepiej scharakteryzować całe

10 Ibidem, s. 133-175.

11 Przedstawione tu zestawienie Celana i Weberna nie jest przypadkowe. Franz Wurm, przyjaciel poety, pisał, iż Celan był mu wdzięczy, gdy porównywał go do Weberna ze względu na zdawkowość poetycką i niezrozumiałość (zob. H. Böttiger, Paul Celan. Miasta i miejsca. Przeł. J. Ekier. Olsztyn 2002, s. 101). Sam Webern jest zaś najbardziej radykalnym kompozytorem z drugiej szko- 
zjawisko. Warto jednak zaznaczyć, że - mimo iż milczenie zostaje w nich wkomponowane w strukturę dzieła sztuki - nie sposób czytać ich przy użyciu narzędzi strukturalistycznych, zaproponowanych w Polsce przede wszystkim przez Stefanię Skwarczyńską w artykule Przemilczenie jako element strukturalny dzieła literackie$g{ }^{12}$. Studium Skwarczyńskiej, choć napisane w latach czterdziestych XX wieku, do dziś uważane jest (także przez Śniedziewskiego czy autorów tomu zbiorowego Semantyka milczenia ${ }^{13}$ ) za istotny punkt odniesienia w badaniach nad literackim milczeniem. Jej typologia przemilczeń wciąż okazuje się funkcjonalna przy konkretnych interpretacjach, jednak praca ta jako całość nie stanowi dla mnie przydatnej inspiracji. W ujęciu Skwarczyńskiej bowiem milczenie może być rozpoznane wyłącznie w kontekście pełnych elementów dzieła, $z$ którymi tworzy spójną strukturę. Ma, oczywiście, status przerwy w ciagłości artefaktu, ale zawsze jest to tylko wyrwa w koherentnym układzie ${ }^{14}$. Milczenie i mowa sa więc $\mathrm{w}$ równym stopniu pozy tywne, gdyż tworzą elementy konstrukcyjne, służące pogłębieniu całości dzieła sztuki.

Dykcja milcząca zmusza zaś do czytania dzieł jako nieciąłych, rozpraszanych przez element bezmowności. Owszem, pełni on funkcję strukturalną (wedle założenia Adorna trzeba, by dzieło bezsensowne wypowiedziało swój bezsens $z$ taka sama precyzją, $z$ jaką dzieło sensowne formułuje swój sens ${ }^{15}$ ), jednak na sposób negatywny: tworząc struktury otwarte, niepełne, wymykające się całości. Lektura milczącego dictum Celana czy słuchanie Weberna zaczyna się nie od rozpoznania układu i jego części, ale od dostrzeżenia niespójności tekstu, która rodzi się z niedopowiedzeń oraz ze strategii desygnifikujących. Dlatego właśnie kategorią pomocną może okazać się „pismo milczenia”; wskazuje ono dobitnie na samoświadomość sztuki w zakresie własnej budowy, nie zakładając jednocześnie, że owa struktura musi być zamknięta czy skończona. Analiza dykcji milczącej wymaga bowiem pochylenia się nad pismem, sposobem kształtowania dzieła - lecz nie może dążyć do stworzenia stabilnej interpretacji odzwierciedlającej jego budowę. Polega raczej na podążaniu za jego ruchem: na poszukiwaniu odpowiedzi na pytanie, co tekst „robi”"16, a nie - czym jest. Postaram się przedstawić taką właśnie koncepcję dykcji milczącej na przykładzie tekstów Celana oraz Weberna, za centralne punkty mojej interpretacji obierając utwór Keine Sandkunst mehr... Celana i Trzy pieśni (Drei Lieder) op. 25 Weberna (do wierszy Hildegard Jone).

Proponowana lektura koncentrować się będzie na tekście-źródle, który nie-

ły wiedeńskiej; jak pisał B. S c häffe r (Klasycy dodekafonii. Część historyczna. Wyd. 2. Kraków 1964, s. 33): „Webern miał skłonność do potęgowania i wyostrzania tych cech, które najbardziej raziły krytyków i kompozytorów u Arnolda Schönberga, był jakby badaczem krańcowych możliwości tego, co Schönberg zaledwie sugerował lub uważał za możliwe".

S. S kw a r c zy ń s k a, Przemilczenie jako element strukturalny dzieła literackiego. W: $Z$ teorii literatury. Cztery rozprawy. Łódź 1947.

13 Semantyka milczenia. Red. K. H a n d ke. Warszawa 1999. - Semantyka milczenia 2. Red. K. Han dk e. Warszawa 2002.

14 Skwarczyńs ka, op. cit., s. 11.

15 Ad or no, op. cit., s. 280-281.

16 Zob. A. Li p s zy c, Rozpisywanie pamięci. W zb.: Kartki Celana. Interpretacje. Red. J. Ros zak. Kraków-Budapeszt 2012, s. 285. 
ustannie zderza się z innymi utworami i jest przez nie oświetlany. Język zarówno Celana, jak i Weberna stanowi przecież całość zamkniętą i zautonomizowana względem rzeczywistości pozatekstowej, a także tradycji artystycznej - wypracowują oni własne sensy dla poszczególnych strategii formalnych czy słów. Najlepiej zaobserwować to można na przykładzie Celana, który nadaje konkretnym wyrazom nowe znaczenia: ich konotacja jest stała, ale jedynie w obrębie języka pisarza. Do owych słów, których sens Celan przekształca, zaliczyć można rzeczowniki (i ich pochodne) takie, jak: „Zeugnis” ‘świadectwo', „Atem” 'oddech', „Schnee” 'śnieg”, "Rose” 'róża', „Niemand” 'nikt', i wiele innych. Webern autonomizuje zaś serię i czyni z niej za każdym razem nowy „alfabet” swojego utworu. Odcina się tym samym od tradycyjnego strukturowania dzieła muzycznego i emocjonalno-symbolicznych konotacji systemu dur-moll, zastępując je pozbawiona pozamuzycznych znaczeń kombinacją dwunastu dźwięków. Obaj artyści tworzą w ten sposób język, który odnosi się sam do siebie i powinien być czytany przede wszystkim w kontekście samego siebie. Podstawowym intertekstem dla interpretatora stają się więc inne teksty danego twórcy. Ich istnienie nie tyle jednak wzmaga spójność systemu stworzonego przez pisarza czy kompozytora, ile pokazuje, jak często autonomizacja struktur prowadzi do wydrą̇enia z sensu - zamknięty świat poezji Celana czy przestrzenie dźwiękowe Weberna jawią się odbiorcy jako nieznaczące abstrakcje, które nie mają swojego desygnatu pozatekstowego. Ich sens nie jest więc pozytywny i nie może być zrozumiany dzięki przełożeniu go na język doświadczenia. Musi pozostać ukryty w samym dziele, nieczytelny przez swoją odrębność wobec rzeczywistości. Dzieło staje się pustą struktura - nie prowadzi to jednak do estetyzacji przedmiotu artystycznego i do koncepcji sztuki dla sztuki, ale raczej do filoz ofii niemego przedmiotu, który w obliczu doświadczeń niejęzykowych (traumy lub mistycznego objawienia) musi pozostać w sferze nieprzetłumaczalnego milczenia.

Przyjrzyjmy się więc tekstowi Celana i podejmowanym przez niego strategiom milczącym:

KEINE SANDKUNST MEHR, kein Sandbuch, keine Meister.

Nichts erwürfelt. Wieviel

Stumme?

Siebenzehn.

Deine Frage - deine Antwort.

Dein Gesang, was weiß er?

Tiefimschnee,

Iefimnee,

$I-i-e .[\mathrm{G} 183-184]^{17}$

17 Wszystkie cytaty z wierszy P. C ela n a oznaczam skrótem G, odsyłającym do wydania: Die Gedichte. Hrsg., komment. B. Wi ed e mann. Frankfurt am Main 2003. Przywołując przekłady polskie, stosuję skróty: $\mathrm{P}=$ Psalm $i$ inne wiersze / Psalm und andere Gedichte. Wybór, przekł. R. Krynicki. Kraków 2013; U = Utwory wybrane / Ausgewählte Gedichte und Prosa. Wybór, oprac. R. Krynicki. Kraków 1998. Liczba po skrócie wskazuje numer stronicy; po średniku podane jest nazwisko tłumacza. 
ŻADNEJ SZTUKI PIASKOWEJ WIĘCEJ, żadnej księgi z piasku, żadnych mistrzów.

Nie wygrane. Ile

niemych?

Siedemnaście.

Twe pytanie - twa odpowiedź.

Twój śpiew, co on tam wie?

Lity śnieg,

Ityśnie,

$$
\text { i - y - e. [U 183; Feliks Przybylak] }
$$

ŻADNEJ WIĘCEJ SZTUKI PIASKU, żadnej księgi piasku, żadnych mistrzów.

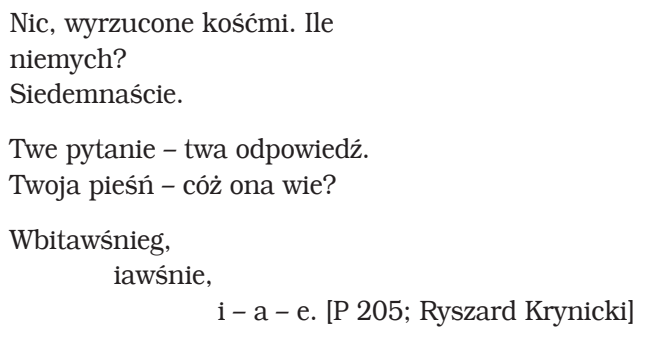

Pierwsza rzecz, która zwraca uwagę w tym wierszu, to jego rozproszenie tematyczne. Znajdziemy w nim nieuzupełniające się plany: metapoetycki (uwidoczniony przez metafory sztuki piaskowej i książki, postać Mistrza, a także śpiew lub pieśń - „dein Gesang”) ${ }^{18}$, nakładający się na niego plan historyczny, przywodzaccy na myśl czas Zagłady (17 niemych), oraz plan natury, przywoływany przez metafore „Tiefimschnee” - „wgłębiśniegu”. Można, oczywiście, dążyć do ich pogodzenia; doświadczenie historyczne przynosi w konsekwencji niemożność konstruowania wypowiedzi artystycznej. Śmierć (uczynienie kogoś niemym) staje się w tej interpretacji również uciszeniem poety, który nie chce już tworzyć nietrwałej, rozpadającej się „sztuki piasku”. Nie godzi się też na terminowanie u mistrzów, podglądanie tradycji. Ona bowiem nie jest w stanie zmierzyć się z traumą Zagłady. Jak jednak w tym połączeniu funkcjonuje plan trzeci - przestrzeń śniegu? Czy biel ma być tutaj synonimiczna wobec niemoty? Czy ma być jedynym czystym elementem w świecie po Zagładzie?

Takie odczytanie wydaje się niemożliwe do zaakceptowania. Po pierwsze, samo złożenie „Tiefimschnee” opiera się na opozycji, sprzeczności. Celan zestawia głębokość i śnieg, ciemność i biel. Zaglądając w głąb, odkryjemy bowiem przeciwieństwo jasności i przejrzystości. Natura nie jest odpowiedzią czystości; sama czystość zaś staje się podejrzana. Połączenie planu poetyckiego i historycznego także nasuwa pewne wątpliwości. Fraza „Nichts erwürfelt” może bowiem oznaczać (i tak tłumaczy

Plan metapoetycki jest zarazem planem ezoterycznym: niemieckie „Sandkunst” było bowiem używane na określenie geomancji. Zob. komentarz B. Wi e d e ma n n do Keine Sandkunst mehr... (G 728-729). Niektórzy interpretatorzy (zob. J. Fel s t i n e r, Paul Celan. Poeta, ocalony, Żyd. Przeł. Maciej Tomal, Małgorzata Tomal. Red. P. Paziński. Kraków-Budapeszt 2010, s. 293) zapominaja jednak o istnieniu kontekstu geomantycznego i czytają motyw „sztuki piasku” jako odrzucenie sztuki czy mistrzów artystycznych oraz wyjście z Mallarméańskiego paradygmatu estetycznego. 
ją Przybylak) „Nie wygrane”, ale pozwala się też odczytać jako „Nic wygrane” (co w swoim przekładzie wyzyskuje Krynicki: „Nic, wyrzucone kośćmi”, dodatkowo podkreślając przypadkowość owego zwycięstwa) - wówczas „Nichts” zaczęłoby funkcjonować w wierszu na takiej samej zasadzie, jak „Niemand” w Psalmie (U 172-173): stałoby się imieniem. Wtedy klęska (interpretowana w duchu problematyki Szoa - jako klęska człowieczeństwa) przemieniłaby się w zwycięstwo Niczego nad Czymś.

Celan, rzecz jasna, nie anuluje w ten sposób tematu Zagłady: wprowadza jednak do tekstu niezborność, której nie da się rozwiązać. Drugi wers pozwala się bowiem czytać na dwa sposoby i przywodzi na myśl dwie sprzeczne interpretacje. Jako że wzajemnie się one wykluczają, do tekstu wkrada się milczenie: być może żadna nie jest miarodajna, być może to, co Celan próbuje wyrazić, nie podlega prawom wypowiedzenia? O p o zy cyj n o ść różnych planów, bardzo częsta w tej poezji ${ }^{19}$, pozwala zaistnieć dykcji milczącej, otwiera dla niej przestrzeń niedopowiedzenia. Czyni tekst niejako obcym wobec czytelnika; nie jest on w stanie przekształcić tego, co czyta, w spójny układ uzupełniających się części. Ich zestawienie wydaje się nieuzasadnione i nie prowadzi do produkcji sensu: tekst nie składa się w całość, ale - wraz z kolejnymi odczytaniami - coraz bardziej się rozprasza, dlatego odbiorca ma wrażenie, że poprzez swoje działanie wzmaga jego bezsensowność. Efekt obcości, do którego dąży liryka Celanowska, przybliża wiersz do ideału bezmownej mowy; języka, który - mimo że jest - nic nie znaczy.

Webern osiaga ów stan za pomocą zupełnie innej strategii. Trudno mówić w jego przypadku o dualizmie tematycznym ${ }^{20}$; kompozytor skupia się na opozycji tekstu i muzyki jako nie współgrających ze sobą elementów. Oczywiście, ten zabieg jest świadomy - jego celem staje się wydobycie wiersza będacego strukturą kontrastująca i absolutna desemantyzacja muzyki ${ }^{21}$. Odbiorca rozpoznaje ów

Znoszące się plany tematyczne pojawiają się w wielu wierszach; dlatego właśnie teksty Celana wydają się hermetyczne, czytelnik nie dostrzega bowiem związku między poszczególnymi obrazami. Tego rodzaju zabiegi moga być, oczywiście, spuścizną po wczesnych zainteresowaniach Celana surrealizmem, jednak - stanowiąc clou jego późnej poetyki - mogą też być interpretowane w kontekście dykcji milczącej. Poeta doprowadza tę strategię do skrajności w wierszu Chymisch, w którym łączy ze sobą plany alchemiczny (gotowanie złota), historycznej Zagłady (spalone imiona) oraz metapoetyckiej refleksji (motyw braku słowa, jego śmierci) (G 134).

20 Kontrastujące tematy pojawiają się także w twórczości dodekafonicznej Weberna, ale w muzyce są one czymś zupełnie uzasadnionym (wystarczy przypomnieć tradycję formy allegra sonatowego). Efekt obcości kompozytor osiąga stosując bardziej wysublimowane metody jukstapozycji tematów. W Das Augenlicht op. 26 dwa pojawiające się tematy nie są zróżnicowane wyrazowo, ale zbudowane przy użyciu przeciwstawnych technik: „Jest to chóralna sonata, w której kontrastujące tematy są reprezentowane nie przez specyficzną m uzy kę, ale przez przeciwstawne te chniki jej tworzenia, nie przypadkiem przez polifonię i homofonię" (K. B a il ey, The Twelve-Note Music of Anton Webern: Old Forms in a New Language. Cambridge - New York 1991, s. 271). Ciekawe jest w pracy Bailey wydobycie dwóch słów, które stanowią człony dyskutowanej opozycji: muzyka-technika. Ów zabieg badaczki pozwala bardzo dobrze uchwycić zintelektualizowany (a tym samym obcy sztuce rozumianej w duchu końca XIX wieku) charakter muzyki Weberna.

21 Na podobną właściwość zwraca uwage także Sc häffer (op. cit., s. 126), choć nie nazywa jej tak radykalnie: „Webern nie poddawał się nigdy tekstowi, nie miał ambicji podkreślania muzyką tekstu, dbał tylko o maksymalną stosowność muzyki”. Sformułowanie „stosowność muzyki” zdaje się tutaj oznaczać odpowiedniość nie tyle wobec tekstu, ile wobec wewnętrznej struktury muzyki. 
chwyt już przy pierwszym odsłuchaniu dzieła. Jako przykład weźmy pieśń I z op. 25, *** (inc. „Wie bin ich froh!"). Wiersz Jone ma charakter ekstatyczny:

\author{
Wie bin ich froh! \\ Noch einmal wird mir alles grün \\ und leuchtet so! \\ Noch überblühn die Blumen mir die Welt! \\ Noch einmal bin ich ganz ins Werden \\ hingestellt \\ und bin auf Erden.
}

[Jak bardzo jestem szczęśliwa! / Znów wszystko staje się dla mnie zielone / i tak błyszczy! / Znów kwiaty ukwiecają świat dla mnie! / Znów jestem cała w stawaniu się / postawiona / i jestem na ziemi. $]^{22}$

Radość z nadejścia wiosny i z możliwości uczestnictwa w misterium natury zostaje tutaj przedstawiona w sposób egzaltowany - poetka wierzy w siłę mówienia niemetaforycznego, niejako $\mathrm{z}$ głębi doświadczenia. W opracowaniu muzycznym nie znajdziemy jednak takiego ładunku emocjonalnego. Otwierająca fraza „Wie bin ich froh!", będąca manifestacja podmiotowości w stanie zachwytu, u Weberna diametralnie zmienia swój sens poprzez użytą dynamikę. Zamiast otwierać się i rozrastać, ona skupia się w sobie, przechodzi od forte do piano. Kompozytor sugeruje więc, by słowo "froh" (które w tekście Jone wydaje się niejako wykrzyknięte światu) zostało wyciszone ${ }^{23}$. Punktowa linia melodyczna akompaniującego fortepianu zderza się z powtarzającymi się eksklamacjami - Webern nieustannie podważa ekstatyczność tekstu swoim ascetycznym opracowaniem ${ }^{24}$. Nie rezygnuje wszakże ze stricte muzycznych kontrastów: zmian dynamicznych oraz dużych skoków interwałowych. Ciagłe wahania w linii wokalnej (oktawy, nony małe i wielkie) moga być potraktowane jako muzyczna reprezentacja uniesienia, jednak wnoszą one do pieśni raczej komponent histeryczny, niepokojący. Całość wydaje się niestabilna, a kontrasty występujące w utworze wykluczają jego nastrojowość. Nie służą więc ilustrowaniu emocjonalnego wymiaru tekstu, tylko destabilizacji sensów: słuchacz nie powinien mieć możliwości dopasowania dźwięków do uczuć, nie powinien dostrzegać między nimi związku. Webern, wprowadzając opozycyjność, pomnaża efekt obcości - muzyka podporządkowuje się jedynie swojej własnej wewnętrznej strukturze, niejako wykluczając tekst $z$ całości dzieła sztuki. Dzięki użyciu prostej techniki podziału (w partiach wokalnych seria jest przekształcana poziomo, nie wchodzi w relacje $\mathrm{z}$ akompaniamentem) kompozytor dodatkowo wzmacnia separację wiersza i opracowania muzycznego. Sam artefakt jawi się więc jako rozdwojony - pozorna bez-

22

Wszystkie cytaty z pieśni A. W e b e r n a (zarówno teksty liryczne, jak i przykłady muzyczne) podaję za wydaniem: Drei Lieder nach Gedichten von Hildegard Jone. Gesang und Klavier op. 25. Transl. E. S mith. Wien 1956. Universal Edition 12418. P. B o u leza 〈Deutsche Grammophon 028945763729 GX 6〉) utrzymane są raczej w dynamice mezzo piano, wówczas kontrast, który mógłby się pojawić, nie zostaje w pełni wykorzystany w interpretacji, a obcość tekstu wobec opracowania muzycznego nie jest jednoznacznie słyszalna.

Odbiorcom współczesnym Webernowi takie potraktowanie wiersza musiało wydawać się wyjątkowo niestosowne, ponieważ - słuchając utworu pierwszy raz i będąc przyzwyczajonym do zasady odpowiedniości tekstu i muzyki, do romantycznej korespondencji sztuk - można by pomyśleć, iż kompozytor kpi z formy i przesłania Jone. Jego strategia polega jednak przede wszystkim na wydobyciu tekstu z faktury muzycznej i zderzaniu ze sobą semantyczności i asemantyczności. 
sensowność połączenia tekstu i melodii staje się zaś świadectwem jego bezmowności: słowo nie znaczy tu w kontekście muzyki, gdyż ta jest niema.

Przestrzeń obcości, kreowana zarówno przez Celana, jak i Weberna, uaktywnia kolejny ważny element dykcji milczącej: s a mozwrotność uży ty ch formuł. W Keine Sandkunst mehr... wers piąty znosi się poprzez swoją tautologiczność. Pytanie staje się równoznaczne $z$ odpowiedzią, ten, kto je zadaje, musi sam rozwiązać tę kwestię. Obie czynności skupiają się więc w jednym podmiocie i okazują się wymienne. „Ty” staje się wyłącznym prawodawcą mowy. To znaczy, że przeciwstawia się „siedemnastu niemym”, jego mowa zaś - niemożliwemu wypowiedzeniu. Źródłowa opozycja języka i milczenia okazuje się jednak (jako pewna całość) zderzona $z$ „Tiefimschnee”, czyli idiomem Niewyrażalności jako takiej. $W$ ten sposób to, co pierwotnie było skontrastowane (mowa-milczenie), zostaje zrównane.

Celanowska samozwrotność objawia się bardzo często poprzez samozaprzeczenie; $\mathrm{w}$ wielu tekstach poeta neguje swoje własne twierdzenia. $\mathrm{W}$ wierszu $\mathrm{Zu}$ beiden Händen... pisze:

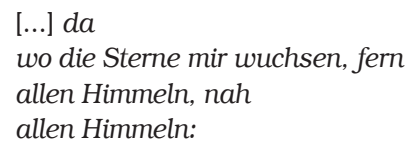

[〈... tam / gdzie gwiazdy mi rosły, dalekie / wszystkim niebom, bliskie / wszystkim niebom:]

Sprzeczne epitety zamykające wersy (,fern”-,nah”, „dalekie”-,bliskie”) służą zbudowaniu znoszącego się wypowiedzenia. Niebo jest jednocześnie bliskie i dalekie, niemożliwe do wyobrażenia. Skoro zaś nie sposób ustalić warunków jego istnienia, określić jego właściwości, samo pojęcie przestaje znaczyć. Jak zauważa Andreas Michael:

Aby potwierdzić istnienie centrum, wyznaczone muszą zostać jego granice. Ale to jest tutaj niemożliwe, ponieważ owe granice są wymienne. To, co „dalekie”, jest też „bliskie”, a „nad” równa się „pod”. Idea „Środka”, z której wyssano znaczenie, powinna okazać się pusta; można wręcz ośmielić się [...] zasugerować, że „O” otwierające ten fragment wciela lub oznacza „pusty... środek”, a zaimek wskazujący „ten" przyciaga do niego uwagę ${ }^{25}$.

Sprzeczność przykuwa wzrok czytelnika do pustego miejsca, u Celana nazwanego ruchomym środkiem. Koncentracja wokół tego, co bezsensowne, pozbawione konotacji, staje się więc krążeniem wokół ciszy. Pomysł Michaela, by traktować „O” jako wizualizację owego środka, wydaje się szczególnie pociagający i naprowadza odbiorcę na ciekawą zbieżność. Jeśli bowiem przypomnimy sobie otwarcie Schönbergowskiego Mojżesza i Arona z jego stopniowym ukonkretnieniem boskiej głoski „o", umieścimy Celana w kontekście mu nieobcym: pustej, milczącej Transcendencji, nieobecnego (choć jakoś istniejącego) Nikogo. Do tego wątku trzeba będzie jeszcze powrócić.

Negacja w Keine Sandkunst mehr... służy przede wszystkim destabilizacji jasnego sensu: ma pokazać splot niemożliwych do skonkretyzowania kategorii, ich wzajemną lustrzanoś ć ${ }^{26}$. Słowa w wierszach Celana przeglądają się w sobie

26 Określenie „lustrzaność” w odniesieniu do poezji Celana należy traktować metaforycznie. W przypadku Weberna terminy „lustrzaność” czy „seria lustrzana” są kategoriami technicznymi i ozna- 
i odkrywają własną tautologiczność. Oddanie mowy w posiadanie $d u$ pozbawia ją intersubiektywności. Całkowicie podporządkowana woli jednej tylko osoby, staje się samozwrotna i przestaje być zrozumiałym komunikatem. Język nie tyle jest rozumiany wyłącznie przez liryczne „ty”, ile wszelkie jego przejawy zostały pozbawione znaczenia. Poeta pyta o mowę, śpiew du: „was weiß er?”, co Przybylak tłumaczy jako „co on tam wie?” Pieśń du nie mówi nic o świecie, nie należy do zewnętrza, ale - w pełni zinterioryzowana - zasklepia się w swojej bezmowności. Mowa okazuje się właściwie tożsama z milczeniem (obie przeciwstawiają się głębi śniegu) jako wyzuta ze znaczeń, martwa, nieadekwatna wobec realności.

Lustrzane formuły, które nie niosą ze sobą pozawewnętrznego sensu, stanowią podstawę estetyki muzycznej Weberna. Spotykamy je niejednokrotnie w budowie serii (Wariacje fortepianowe op. 27), a także w konkretnych przekształceniach materiału muzycznego. W pieśni III $z$ op. 25 odbijające się wzajemnie linie melodyczne pojawiają się w dwóch miejscach:

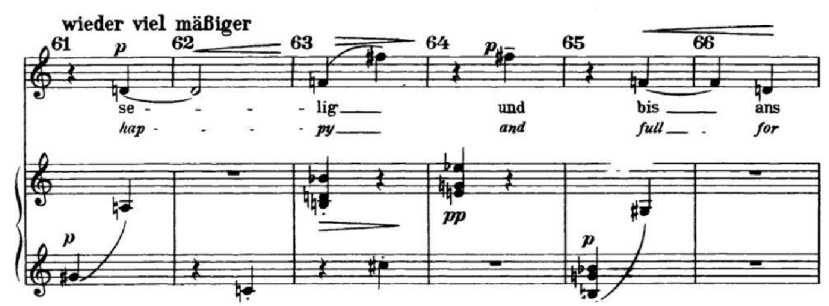

Przykład 1: Anton Webern, Trzy pieśni op. 25, pieśń III
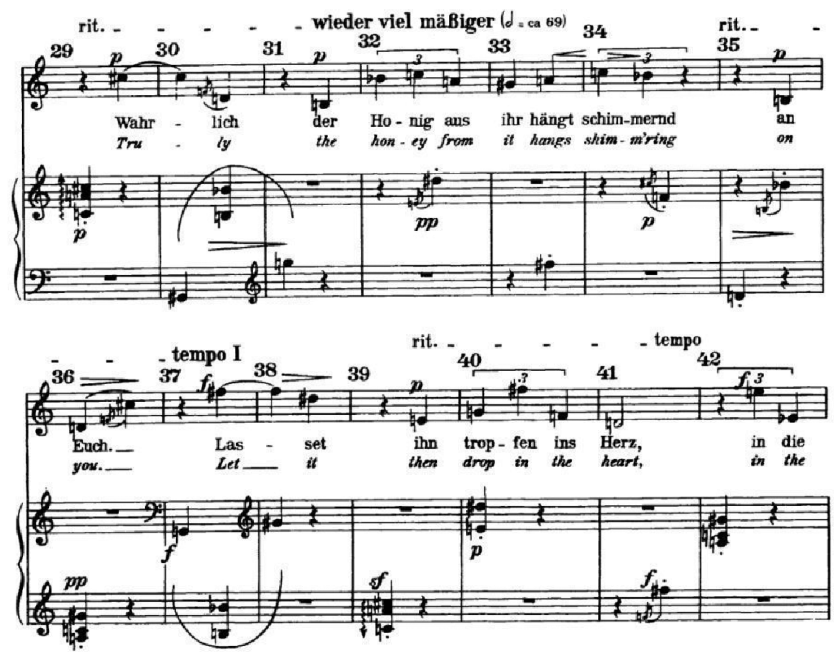

Przykład 2: Anton Webern, Trzy pieśni op. 25, pieśń III

czają specyficzny sposób strukturowania tworzywa muzycznego (np. serię lustrzaną wobec podstawowej stanowi seria w inwersji, czyli taka, w której zachowane zostają identyczne interwały między kolejnymi dźwiękami, ich kierunek jest natomiast odwrotny). Celan tworzy struktury lustrzane za pomocą słów, które pozostają samozwrotne, mimo pozornej różnicy są tym samym (jak w przypadku wersu „Deine Frage - deine Antwort” z Keine Sandkunst mehr...). 
W pierwszym przykładzie, oprócz oczywistego powtórzenia linii głosu w raku, mamy też do czynienia $z$ lustrzanymi akordami w partii fortepianowej. $\mathrm{W}$ taktach 63-64 kompozytor dubluje tę samą budowę trójdźwięku (8-3), by w następnym ją odwrócić (3-8). W ten sposób odbiciu podlegaja zarówno poziome, jak i pionowe struktury. Pytanie, które można by sobie postawić w przypadku Weberna, brzmi: czy takie zabiegi mają w jego pieśni uzasadnienie pozamuzyczne? I - co nie mniej ważne - dlaczego konstrukcje lustrzane są u niego tak częste i istotne? W pieśni II z op. 25 kompozytor opracowuje na tę modłę fraze „Wahrlich der Honig aus ihr / Hängt schimmernd an Euch [Doprawdy, miód od nich 〈tj. kwiatów miłości〉 / zwisa, oświetlając was]". Teoretycznie możliwe byłoby odczytanie plastra miodu jako tafli lustra, jednak taka interpretacja nie wydaje mi się przekonująca. Miód w wierszu nie tyle odbija światło, ile je $z$ siebie generuje, staje się miłosną esencją, która promieniuje wewnętrznym blaskiem. Linia melodyczna - znów w opozycji do tekstu - zamyka się zaś w sobie; zamiast być zwierciadłem dla sensu, koncentruje się jedynie na własnym odbiciu, jak gdyby chciała podziwiać doskonałość swojej budowy $^{27}$. Narcystyczne lustra Weberna skrywają więc tylko tajemnicę muzyki, a nie sekret znaczenia płynącego od słów; mowa luster pozostaje niesygnifikatywna.

Być może, dlatego właśnie wydają się one tak ważne dla zrozumienia idei stojącej za muzyką Weberna. Czym bowiem jest lustro? Rzeczą, która zwraca nam samych siebie. Ale też czymś, co skupia nas w sobie, w oderwaniu od zewnętrzności. Moment spoglądania na swoje odbicie zawsze wiąże się $z$ intymnością, $z$ oddzieleniem się od realności. Zwierciadło czyni człowieka pojedynczym - odbiera mu wszelkie konkretne zakorzenienia, oddaje go abstrakcji. Webern zdaje się cenić lustrzaność, ponieważ dzięki niej muzyka staje się samozwrotna, skupiona na sobie jako tworze bez znaczenia. $Z$ chwilą osiagnnięcia owej bezznaczeniowości zyskuje zaś treść innego rodzaju.

Interpretując rozstrzygnięcia techniczne Weberna jako pochodne tego rodzaju myśli, zobaczymy, że w istocie bardzo głęboko rozumie on wybraną przez siebie poezję Jone ${ }^{28}$. Jej przetworzenie dokonuje się jednak na ogólnym poziomie idei i filozofii sztuki, nie polega więc na ilustracyjności czy odpowiedniości wyrazowo-

27 Podobna tezę stawia polska monografistka kompozytora, L. S taw owy (Webern. Kraków 1992, s. 179), w odniesieniu do Wariacji fortepianowych op. 27: „Faktura tych fragmentów jest autonomiczna, wynika w prostej linii z formacji lustrzanych, osiowych. Webern geometryzuje tworzywo muzyczne, nuty nie mają tu właściwie swojego pierwotnego znaczenia, są tylko oparciem dla kombinacji dźwiękowych, które analizuje się ze stale rosnacym zachwytem dla geniuszu kompozytora”. W ustępie z pieśni III z op. 25 sprawa także jest bardziej skomplikowana, niż pokazuje to umieszczony w niniejszym tekście przykład. Cała fraza (rozpoczynająca się od taktu 19, a kończąca się na takcie 40) stanowi prezentację serii najpierw w raku w inwersji, a następnie w jego mechanicznym odwróceniu (czyli raku raka w inwersji). Lustrzaność wydaje się tutaj podwojona fragment $z$ taktów 33-40 to bowiem odbicie odbicia serii podstawowej.

28 Warto zauważyć, że Webern bardzo wysoko cenił lirykę Jone i utrzymywał z poetką bliskie, przyjacielskie stosunki, czego dowodzą wymieniane przez lata listy. Wielokrotnie w jego korespondencji powraca przeświadczenie o zgodności ich światopoglądów i przekonań artystycznych (zob. A. W e b e r n, Letters to Hildegard Jone and JosefHumplik. Ed. J. P oln a u e r. Transl. C. C a r d e w. Bryn Mawr, Pa., 1967). Na bliskie relacje między Webernem a Jone oraz jej mężem, J. Humplikiem, zwraca uwagę także Staw ow y (op. cit., s. 161), podkreślając jednak, że poetka była muzą kompozytora „w najczystszym tego słowa znaczeniu”. 
-emocjonalnej między tekstem a muzyką. Jone próbuje w wierszu *** (inc. „Sterne”) uchwycić moment ekstatycznego doznania jedności z naturą i miłości, która się wówczas wytwarza:

\author{
Sterne, Ihr silbernen Bienen \\ der Nacht um die Blume der Liebe! \\ Wahrlich, der Honig aus ihr \\ Hängt schimmernd an Euch. \\ Lasset ihn tropfen ins Herz, \\ in die goldene Wabe, \\ füllet sie an bis zum Rand. \\ Ach, schon tropfet sie über, \\ selig und bis ans Ende mit \\ ewiger Süße durchtränkt.
}

[Gwiazdy, Wy srebrne pszczoły / nocy wokół kwiatów miłości! / Doprawdy, miód od nich / zwisa oświetlając Was. / Pozwól mu wpuszczać krople do serca, / w złotym plastrze miodu. / Wypełnia go aż po brzeg. / Ach, już przelewa się, / błogi ${ }^{29}$ i aż do końca / wieczną słodyczą przesączony.]

Słodycz nocy i miłości przepełnia serca bohaterów wiersza - nie jest to jednak przyjemność tymczasowa, przynależna do sfery ludzkiego odczuwania. Miłość w liryce Jone aspiruje do wieczności: poetka opisuje ja jako małą śmierć, która objawia tajemnicę (w tym wierszu kryje się ona w „złotym plastrze miodu”). Sensualność, radość $\mathrm{z}$ obcowania $\mathrm{z}$ naturą często wiąże się u Jone $\mathrm{z}$ doświadczeniem religijnym; także tutaj metaforykę sensualną (słodycz, przelewanie się miodu, błogość) można interpretować jako odsyłającą do Absolutu wcielonego w przyrodę. Bohaterowie sa „przesączeni” słodyczą miodu - on zaś skrywa w sobie sekret wiecznej miłości. To, co zmysłowe - podobnie jak u Rilkego - transcenduje tu w stronę boskości. Wypełnieni po brzegi kochankowie wchłaniaja Absolut całym swoim ciałem; jak zwykle u Weberna - panteistyczna wizja natury, w której materialnej postaci przejawia się Bóg, również i tutaj znajduje swoje odbicie.

Bezznaczeniowość tej muzyki jest więc spełnioną ekstazą Jone. Melodia, która przegląda się w samej sobie, która się sobą wypełnia, osiagając beztreściowość i całkowite skupienie, stanowi muzyczny ekwiwalent pełni doświadczenia zmysłowo-religijnego. Niemota dzieła Webernowskiego odpowiada bowiem na milczenie głębsze, mistyczne. Brak znaczenia, puste miejsce po emocjach to punkt, w jakim będzie mogła pojawić się na chwilę cisza boskości - to dla niej kompozytor na granicy między odbiciami dźwięków próbuje otworzyć prześ wit.

Próby Weberna są więc jednocześnie odległe od strategii Celana oraz bliskie im. Poeta ten nie postrzega pustki jako czegoś opatrzonego „znakiem dodatnim”30; jego

Słowo „selig” można tłumaczyć jako 'błogi' lub 'zmarły'.

Dobrą formułą na określenie Webernowskiego milczenia jest, moim zdaniem, „nic ze znakiem dodatnim" J. Przy b o si a (Znak dodatni. W: Utwory poetyckie. T. 2. Przedm. J. Kw i a t kow s ki. Red. Z. i S. Gó r ow i e. Kraków 1994, s. 305). Cisza odsyła do Absolutu, staje się zastępnikiem Niewyrażalnego. Warto tu przywołać fascynacje religijne Weberna, który głęboko wierzył w sens objawiony poprzez to, co na granicy materialności, co ulotne, związane z nieobecnością: światło (w Das Augenlicht op. 26), wiatr i zapach (w I Kantacie op. 29) czy milcząca ciemność (w II Kantacie op. 31). Nicość, bezznaczeniowość czy cisza są dla niego zawsze opatrzone pewną pozytywnością: pustka wyrazu staje się pełnią boskości. 
Nic lub Nikt faktycznie pozostają oddzielone od człowieka zasłoną milczenia. Nawet jeśli zinterpretujemy tę lirykę w kontekście apofatyzmu lub kabalistycznego przekonania o wycofaniu się Boga (cimcum), nadal pozostanie ona głęboko zasklepiona w swojej negatywności. Celan nie wierzy bowiem w możliwość unii mistycznej, pojednania z Absolutem - zbyt tragiczna jest jego biografia, doświadczenie ostańca. W przeciwieństwie do Weberna (ze względu na różnicę momentu historycznego, w jakim rodzi się ich twórczość), traktuje Celan dykcję negatywną przede wszystkim jako obowiązek wobec drugiego człowieka i jego historii. Cisza świata, z którą nieustannie się konfrontuje, uświadamia mu zaś jeszcze mocniej jego własną samotność oraz niemoc. „Martwy język”31 nie może już opowiedzieć ani pojedynczego losu, ani tragedii narodu, ani - tym bardziej - pochwycić Tego, którego nie ma. Objawia się On bowiem tylko jako pustka po sobie, jako pęknięcie. O ile Webernowska cisza jest więc próbą przeniesienia się na drugą stronę, próbą unii mistycznej, o tyle Celanowskie milczenie opatrzone zostaje świadomością, iż czeka tam na nas jedynie ta sama rana, ten sam Nikt. Mimo owej różnicy obaj artyści schodzą coraz głębiej w sferę bez głosu: radykalizują swoją dykcję, dążąc do wydestylowania ze słowa tego, co może być jego rewersem.

Próby stopniowego osłabiania znaczenia prowadzą ich zaś do coraz większej abstrakcjonizacji tworzywa artystycznego. U Celana wiąże się ona ze stwarzaniem wewnętrznych konotacji (wyrazy znaczą coś jedynie w obrębie świata poetyckiego, stają się niejako słowami-kluczami, od razu odnoszac czytelnika do konkretnych sensów), a także ze zmniejszaniem liczby używanych rzeczowników, wyrazów o jasno określonych desygnatach, z wyróżnianiem zaimków, rodzajników i innych części mowy o funkcji strukturalnej, a nie znaczeniotwórczej. To ciekawe, że Celan lubuje się w umieszczaniu na końcu wersu bądź w osobnym wersie (czyli w miejscach zwracających uwagę czytelnika) zaimków, rodzajników oraz przyimków (niejednokrotnie rozbija czasownik złożony, aby pozostawić przyimek w klauzuli). Takie zabiegi znajdziemy w wielu jego najbardziej znanych tekstach:

Vom Zuviel war die Rede, vom

Zuwenig. Von $\mathrm{Du}$

und Aber-Du, von

der Trübung durch Helles, von

Jüdischem, von

deinem Gott.

(Zürich, Zum Storchen, G 126)

Wie man zum Stein spricht, wie

du,

mir vom Abgrund her, von

einer Heimat her Ver-

\author{
Mowa była o nadmiarze, o \\ braku. O Ty \\ i nader-Ty, o \\ zmąceniu przez jasność, o \\ żydowskości, o \\ twoim Bogu.
}

(Zurych, Zum Storchen, P 161; R. Krynicki)

Tak jak się mówi do kamienia, jak

ty

mi już z owej otchłani, $\mathrm{z}$

rodzinnych stron mi spo-

31 Śmierć języka, a w szczególności języka niemieckiego, pojawia się także w refleksji G. S t e i n e r a (The Hollow Miracle. W: Language and Silence: Essays 1958-1966. London 1985). Jego tezy dotyczące nieusuwalnej skazy Zagłady, która naznaczyła niemczyznę, można chyba odnieść do poetyki milczenia Celana (choć sam Steiner nie wspomina o tym poecie w swoim eseju The Hollow Miracle z 1959 roku): „niewypowiadalne było mówione, wciąż na nowo, przez dwanaście lat. To, co 
schwisterte, $\mathrm{Zu}$ -

geschleuderte, $d u$

(Radix, Matrix, G 140) krewniona, przy-

rzucona, ty

(Radix, Matrix, U 141; F. Przybylak)

Szczególnie wyraźne wydają się one w cytowanym fragmencie Zurych, Zum Storchen. Wieńczący właściwie każdy wers przyimek „o” („von”) służy jego otwarciu, postawieniu pytania o coś. Odpowiedź znajduje się jednak dopiero w następnej linii - przestrzeń między nimi wypełnia się w ten sposób niedopowiedzeniem, ciszą. Między przyimkiem a rzeczownikiem tworzy się wyrwa milczenia. W Keine Sandkunst mehr... Celan tylko raz zawiesza tak głos: „Wieviel / Stumme?” - pisze. Zaimek „ile” użyty we wskazanym miejscu także otwiera wiersz na kilka co najmniej odczytań. Tuż przed pytaniem pojawia się bowiem motyw rzutu kością. Jego wynik - nic staje się więc przedmiotem badań. Celan docieka: ile to nic? jak wiele znaczy? co się w nim kryje? W następnym wersie precyzuje jednak, że pragnie określić liczbę „niemych” („die Stumme”). W tym miejscu czytelnik staje wobec problemu nakładających się na siebie pól znaczeniowych. Uświadamia sobie, że die Stumme to mogą być ludzie (którym odmówiono prawa głosu, odebrano mowę, którzy „oniemieli" w wyniku jakiegoś wydarzenia), ale że owo słowo może również odnosić się do oczek na kościach, zasad - sygnalizowanej w wersie otwierającym - geomancji ${ }^{32}$. Skoro bowiem poeta odrzuca wróżbę, zarówno w postaci Sandkunst, jak i Sandbuch, odrzuca też postać Mistrza-Geomanty - szesnaście figur przestaje odsyłać do sensu: cała praca wróżbity okazuje się bez znaczenia. Dlaczego jednak liczbą określająca niemych jest siedemnaście, a nie szesnaście?

Celan wprowadza czytelnika w świat wewnętrznych $z$ a ga de k. Siedemnastka dziwi; uruchomione w trakcie lektury konteksty nie są w stanie jej wyjaśnić. Szyfr użyty tu przez poetę znów otwiera przestrzeń dla milczenia. Nie dość, że liczba określa to, co bezmowne, to jeszcze zawiera pewien naddatek, jest „nadliczbowa”. W geomancji wyróżnia się bowiem szesnaście kombinacji ${ }^{33}$; siedemnasta byłaby tą niemożliwą. Skoro jednak poeta losuje „nic”, to być może odkrywa tę właśnie - nie istniejąca kombinację? Wówczas rzut kością stanowiłby synonim odkrycia tajem-

nie do pomyślenia, było spisywane, umieszczane w indeksach, katalogowane. [...] Język użyty, by zorganizować piekło, wprowadził piekielne nawyki do swojej składni. Użyty, by niszczyć w człowieku to, co ludzkie, i oddać pod rządy tego, co bestialskie. Stopniowo słowa straciły swoje pierwotne znaczenie i nabrały koszmarnych sensów" (s. 122).

B. Wiedemann w swoim komentarzu krytycznym do wierszy Celana przywołuje zdanie ze wstępu G. E i s a do Wahrsagetexte des Spätmittelalters: „Geomancja lub sztuka piasku (arabskie al-raml 'wiedza o piasku') jest zamierzchła metodą przewidywania przyszłości" (cyt. za: B. Wi ed e m a n n, Kommentar. G 728).

33 Geomancja postrzega szesnastkę jako liczbę doskonałą; jak przypomina A.-M. C a c ci a g u e r r a (Geomancja wróżebna, czyli Sztuka przepowiadania przyszłości. Przeł. E. S ę k o w s k a. Białystok 2003, s. 11-12, 65), jest to jedyna liczba całkowita, którą da się przedstawić w postaci poteg $x^{y}$ oraz $y^{x}$, gdzie $x^{y}=y^{x}\left(\right.$ np. $\left.2^{4}=4^{2}=16\right)$. Szesnaście figur geomantycznych powstaje $\mathrm{w}$ wyniku intuicyjnego zapisania kresek na piasku (stąd nazwa wykorzystana w wierszu Celana: „sztuka piasku”), uporządkowania ich według kryterium parzystości i utworzenia konkretnych figur geometrycznych (Droga, Grupa, Postęp, Kameleon, Związek, Cela, Powodzenie, Zła Passa, Utracjusz, Fortuna, Czerwień, Biel, Przygoda, Zwycięstwo, Femina, Mascula). Ich interpretacja symboliczna pozwala przewidywać przyszłość. 
nicy, dotarcia do sensu chroniącego się $\mathrm{w}$ ciszy ${ }^{34}$. Dlatego właśnie sztuka piasku przestaje być potrzebna, a księga sama się unieważnia. Jednocześnie $z$ innych tekstów Celana pamiętamy, że wartość dodana jest u niego często „naddatkowa utrata" 35 - obok znikania konkretnych osób, ich śmierci w ciagu drugiej wojny światowej, musi wykrystalizować się strata, która realnie nigdy nie miała miejsca, ale jest „własna”, należy tylko do poety. Taką funkcję w wierszu Chymisch pełni postać siostry. Jak wiadomo, Celan nigdy jej nie miał. Staje się ona wszakże jedną z głównych bohaterek jego wierszy ${ }^{36}$. Kim jest i co oznacza? Być może, stanowi upostaciowienie owej nadliczbowej śmierci, zastępnik śmierci własnej, przegapionej, wykradzionej losowi? Byłaby wtedy siedemnastą niemą i znosiłaby pozytywną interpretację odkrycia przyszłości. Siedemnasta kombinacja wyrzucona kośćmi - nieobecna siostra-nic - anulowałaby wszystkie pozostałe figury, nie dając w zamian żadnego rozwiązania. Wróżba zostałaby definitywnie zaprzeczona jako niemożliwa w obliczu tej naddatkowej ofiary.

Moim obowiązkiem jest jednak zapisać tę drogę interpretacyjną w trybie przypuszczającym - przecież siostry nie ma w Keine Sandkunst mehr..., przecież liczba siedemnaście wcale nie musi odnosić się do geomancji, a może zostać odczytana przy wykorzystaniu symboliki liczb lub zgodnie z zasadami gematrii. Jakkolwiek byśmy próbowali uzgodnić ją z tekstem wiersza, zawsze pozostanie nam naddatek (siedemnasta ewentualność?), którego nie sposób włączyć w całość. Strategia zagadki właśnie w owej resztce umieszcza swoje milczace znaczenie.

Fascynacja Celana ezoteryka (stałe wykorzystywanie metaforyki alchemicznej, wątek geomancji) doskonale współgra $z$ Webernowskim zainteresowaniem matematyką i idea kwadratu magicznego. To, co u poety ulega abstrakcjonizacji poprzez

Do podobnych wniosków, choć przyjmując inne założenia, dochodzi Fels tin er (op. cit.) w swojej interpretacji Keine Sandkunst mehr... Siedemnastkę postrzega on wszakże jako niepełną osiemnastkę z modlitwy szemone esre (Osiemnaście błogosławieństw): „Być może "siedemnastu" brakuje jednego do "Osiemnastu błogosławieństw", centralnej modlitwy liturgii żydowskiej, albo do sumy 18 , która jest numerycznym odpowiednikiem hebrajskiego słowa "żywy"” (s. 293). Taka interpretacja wzmacnia problematykę Zagłady i jasno dowodzi, że siedemnastu niemych to zabici Żydzi (brak osiemnastki oznacza tu brak żywego człowieka). Zarazem pominięcie osiemnastego błogosławieństwa, będącego pochwałą Boga - sprawcy pokoju („Użycz pokoju w Izraelu, Ludzie Twoim, i w Twym mieście i dziedzictwie i błogosław nas, wszystkich nas w jedności. Błogosławionyś Ty, o Panie, sprawco pokoju!" (cyt. z: Religie Wschodu i Zachodu. Wybór tekstów źródłowych. Red. K. B a n e k. Warszawa 1991, s. 234 (przeł. S. C in a 1))), może stanowić deklarację Celana o odejściu od judaizmu w imię pamięci o zamordowanych.

Określenie to i wynikającą z niego interpretację zawdzięczam dyskusji o wierszu Chymisch podczas seminarium Paul Celan: język i Zagłada, prowadzonego przez A. Lipszyca w Instytucie Studiów Zaawansowanych w roku akademickim 2012/13.

36 Postać siostry powraca m.in. w wierszach Regenflieder, „Jestem sam...” („Ich bin allein...” 〈U 36-37〉), Kiedy tu, oślepiony... (Da du geblendet 〈P 68-69〉), Krajobraz (Lanschaft 〈P 70-71〉), Śluza (Die Schleuse (P 168-169〉). F els ti ner (op. cit., s. 29) przywołuje też w swojej biografii Celana znaczący dla tego zagadnienia fakt - w latach trzydziestych, kiedy poeta zaangażował się w zbiórkę pieniędzy dla republikanów hiszpańskich, „wymyślił nawet starszą siostrę i opowiadał o jej dokonaniach w czasie wojny domowej w Hiszpanii po to tylko, by pytano go później, co się z nią stało”. Badacz stawia również ciekawą tezę, iż wiersze paryskie z lat 1950-1951, w których nagminnie powraca postać siostry, są próba przepracowania utraty ukochanej matki; tym samym siostra staje się znakiem dojmującego braku (s. 96). 
zanurzoną w irracjonalności tajemniczość, u kompozytora staje się przedmiotem zagadki logicznej, która jednak - za sprawą wewnętrznej spójności - odnalazła swoje miejsce także w tradycji hermetycznej. Ulubionym rebusem Weberna był słynny kwadrat magiczny Sator:

\begin{tabular}{|c|c|c|c|c|}
\hline $\mathrm{S}$ & $\mathrm{A}$ & $\mathrm{T}$ & $\mathrm{O}$ & $\mathrm{R}$ \\
\hline $\mathrm{A}$ & $\mathrm{R}$ & $\mathrm{E}$ & $\mathrm{P}$ & $\mathrm{O}$ \\
\hline $\mathrm{T}$ & $\mathrm{E}$ & $\mathrm{N}$ & $\mathrm{E}$ & $\mathrm{T}$ \\
\hline $\mathrm{O}$ & $\mathrm{P}$ & $\mathrm{E}$ & $\mathrm{R}$ & $\mathrm{A}$ \\
\hline $\mathrm{R}$ & $\mathrm{O}$ & $\mathrm{T}$ & $\mathrm{A}$ & $\mathrm{S}$ \\
\hline
\end{tabular}

Kompozytor przywołuje go na zakończenie wykładów zebranych w książce Der Weg zur neuen Musik. Fraza „Sator arepo tenet opera rotas” staje się podsumowaniem jego przemyśleń nad twórczą swobodą w ramach techniki dodekafonicznej. Nowy szlak, jakim podąża muzyka eksperymentalna, wydaje mu się drogą większej wolności, ponieważ wszystkie elementy mają w tej muzyce „głębszą jedność”37. Zdaniem Weberna, ograniczenie kombinacji serii pozwala wytworzyć takie poczucie zależności wszystkich składników kompozycji, że zarówno odbiorca, jak i artysta doświadcza wówczas prawdziwej wolności od przypadku³8. W wykładzie z 2 III 1932 kompozytor podkreśla:

Im dalej ktoś się posuwa, tym większa staje się identyczność wszystkiego i wreszcie dochodzimy do punktu, w którym mamy wrażenie, że stanęliśmy twarzą w twarz z dziełem nie ludzkim, ale z dziełem Natury ${ }^{39}$.

Kwadrat magiczny stanowi więc dla niego wcielenie owej głębokiej jedności myślowej, strukturalnej oraz duchowej. Dzieło sztuki przestaje być tylko igraszką matematyczna; jego logiczny ład, poddanie jasno określonym zasadom i przekształceniom, odbija pierwotną spójność Natury.

Dwanaście wybranych dźwięków okazuje się zatem nie tylko punktem wyjścia dla kompozycji (jak u Arnolda Schönberga czy Albana Berga, którzy podporządkowali serię innym cechom własnego języka muzycznego), ale ma try c a - praca nad nią pochłania niejednokrotnie więcej czasu niż późniejsze kształtowanie utworu. Jak słusznie pisał Schäffer:

Dla Weberna komponowanie jest tylko realizowaniem możliwych wariantów, których jakość zawarta jest już w samej serii, często wybranej starannie pod kątem nie napisanej jeszcze i nie przewidzianej muzyki ${ }^{40}$.

Ów tajemniczy pochód dźwięków ma zawrzeć w sobie substancję dzieła muzycznego, dlatego podlega rygorystycznym zasadom: im doskonalszy pod względem

A. Webern, The Path to the New Music. Ed. W. Re ich. Transl. L. Bla ck. Bryn Mawr, Pa., 1963, s. 55.

38 Ibidem, s. 56.

39 Ibidem.

40 Schäffer, op. cit., s. 129. 
formalnym, tym lepiej nadaje się do dalszej pracy twórczej. Seria wykorzystana w op. $25^{41}$ podzielona została na 4 odcinki 3-dźwiękowe, $z$ których - jak zauważa w swojej analizie Ludomira Stawowy - „aż trzy mają taką samą strukturę interwałową (sekunda mała i tercja mała)"42. Można powiedzieć, iż trzecia komórka ( $a$ - cis - gis) dysonuje względem pozostałych, mających identyczną budowę. Powtarzają się w nich nie tylko odległości, ale również kierunki ich zmiany (interwały są zawsze opadające - $\mathrm{w}$ trzecim zestawie mają zaś strukturę wznosząco-opadająca). Ponadto, o ile w bliźniaczych odcinkach Webern umieścił interwał dysonansowy, o tyle w trzeciej trójce znalazły się tercja wielka i kwarta czysta. Najbardziej konsonansowa komórka okazuje się, paradoksalnie, nie pasować do układu całości.

Szczególnie ważne jest, że Webern - mimo wprowadzenia rozmaitych przekształceń serii zarówno w pionie, jak i w poziomie - w pieśniach $\mathrm{z}$ op. 25 traktuje podstawowe 12 dźwięków dość linearnie, dzięki czemu słuchacz szybko rozpoznaje kolejne odbicia wyjściowego układu. Ciekawym zabiegiem wydaje się jednak podkreślanie charakterystycznej budowy serii poprzez łamanie zasady linearności. W ostatniej z pieśni, kiedy kompozytor dokonuje kolejnej prezentacji postaci wyjściowej, właśnie w trzeciej (konsonującej) komórce dochodzi do rozbicia struktury poziomej i powstania pionowej - dalsza część kombinacji ułożona jest akordowo:
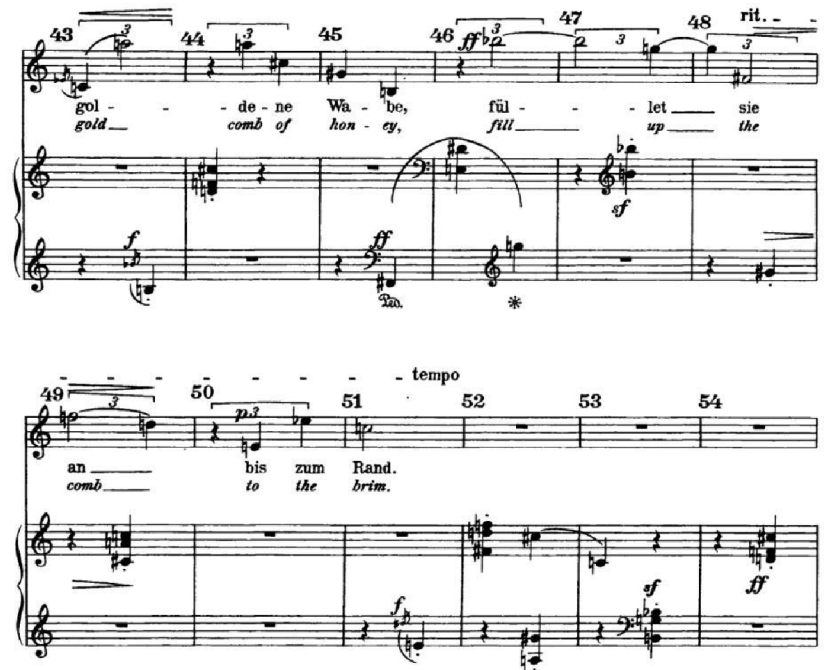

Przykład 3: Anton Webern, Trzy pieśni op. 25, pieśń III

Seria podstawowa zostaje wprowadzona dźwiękiem fis w takcie 48 i rozwija się linearnie aż do $c$ w takcie 51 - tam właśnie dochodzi do rozłamu. Kompozytor nie

41 Cały cykl pieśni zbudowany jest w oparciu o jedną kombinacje (jej postać wyjściowa to: fis $-f-d$ $-e-e s-c-a-c i s-g i s-h-b-g)$, co wzmaga jego strukturalną zwartość i czyni jeszcze mocniej asemantycznym: materiał dźwiękowy nie ma szansy w żadnym stopniu odzwierciedlać tematyczno-wyrazowej zawartości poezji. 
tylko powtarza akordowo dwie pierwsze, już zaprezentowane komórki, ale również dalszą część segmentu pozostawia jedynie w opracowaniu pionowym. W obliczu konsonansu nie pasującego do całości głos załamuje się i milknie.

Mnożenie opozycji i niemożliwych do uzgodnienia planów, samozwrotność tekstu i negowanie jego potencjalnych znaczeń, dążenie do desemantyzacji, a także poszukiwanie milczacych sensów w zagadkach to jednak nie wszystkie strategie dykcji milczącej. Stanowią one bardzo często jej zaplecze konceptualne i umożliwiają bardziej bezpośrednie ujawnienie się ciszy w tekście. Te szczegółowe zabiegi są zaś ściśle związane $z$ tworzywem dzieła sztuki, dlatego różnicują się w konkretnych dyscyplinach. Postaram się pokazać pewne zależności między nimi, choć nie wszystkie da się ze sobą uzgodnić, porównać czy połączyć. Zestawienie owych mikrostrategii u Celana i Weberna pozwoli jednak zobaczyć, że - mimo odmienności dziedzin sztuki reprezentowanych przez nich - chwyty owe prowadzą do osiągnięcia tego samego celu: dewaluacji dotychczasowego języka i zastapienia go bezmowną mową.

Jej najważniejszym literackim przejawem staje się zanik słowa, jego rozpraszanie, rozbijanie oraz - w konsekwencji - skupienie się na pojedynczej literze jako nieznaczącym znaku. U Celana najczęściej spotykaną strategia jest r o z b i c i e wyrazu na dwa elementy; pojawia się ona w oczywistym kontekście kryzysu języka i jego mocy wyrażania:

$\begin{array}{ll}\text { Ihr meine mit mir ver- } & \text { Wy, moje, ze mna u- } \\ \text { krüppelnden Worte, ihr } & \text { łomne słowa, wy, } \\ \text { meine geraden. [G 139] } & \text { moje proste [P 174-175; R. Krynicki] }\end{array}$

W wierszu ...szumi źródło (...rauscht der Brunnen) imiesłów określajacy słowo poetyckie zostaje podzielony; „verkrüppelnd" oznacza, rzecz jasna, 'bycie ułomnym' (w sensie kalectwa), ale może być także odczytane jako 'oniemienie', 'zaniemówienie'. Wyraz okazuje się więc bezgłośny i, podobnie jak poeta, pozbawiony umiejętności wypowiedzenia sensu. Jednocześnie - poprzez rozdzielenie przedrostka „ver-" i rdzenia „krüppeln” - Celan wydobywa jego pejoratywne nacechowanie; rzeczownik „der Krüppel" to po prostu 'kaleka'. Język zostaje przedstawiony jako nie tylko złamany (poprzez wprowadzenie znaku podziału wyrazów), lecz także ostatecznie pokonany, niezdolny już do regeneracji. Poeta na oczach czytelnika dokonuje więc podwójnej operacji: poniża słowo i jednocześnie się $z$ nim utożsamia, wyzywa je i otacza opieką. Sam jest bowiem dotknięty identycznym kalectwem: niemożnością przepracowania własnego traumatycznego doświadczenia.

Dla Celana rozbicie wyrazu stanowi świadectwo mowy naznaczonej cierpieniem. Czym byłoby więc scalenie, takie jakie zaobserwować możemy w Keine Sandkunst mehr...? Ostatnią strofę tego utworu otwiera zbitka „Tiefimschnee”, która w przekładzie filologicznym na język polski brzmiałaby „głębokowśniegu”. Słowa zostają zapisane w jednym ciąu, bez przerwy. Można potraktować je jako kolejne wcielenie Celanowskiej zagadki. Połączenie głębokości i śniegu budzi skojarzenia z obrazem pojawiającym się w Rozmowie w górach (Gespräch im Gebirg 〈U 304-311〉): schodzeniem w głąb lodowca, ku naturze rzeczy. Istotne jest jednak przede wszystkim to, że w następnych wersach utworu Keine Sandkunst mehr... kolejne litery owego rebusu znikają. Zupełnie jakby odbiorca był prowadzony do jądra tajemnicy, 
miał pochwycić ją samą, a nie jej słowną reprezentację. Ostatnie samogłoski zwracają człowiekowi nie zapośredniczona przez znaczący język prawdę.

Zaprezentowane odczytanie nabiera bardzo teologicznego sensu, jeśli przypomnimy sobie, jak istotna jest w tradycji judaistycznej rola samogłoski. Konstrukcja pisma hebrajskiego, w którym samogłoska staje się ukrytą, wymagającą odszyfrowania zagadką, pozwala nam sądzić, że Celan traktuje ją jako nie zapośredniczoną, nie zafałszowaną przez językową reprezentację prawdę o Bogu. Samogłoska (w Keine Sandkunst mehr... - wydestylowany z głębi śniegu pochód „i-i-e” 〈G 184〉) jest odkryciem Imienia. Wymawiając ją, umieszczając w klauzuli wiersza, Celan dokonuje zdjęcia pieczęci $z$ tajemnicy ${ }^{43}$, obnaża przed czytelnikiem siedemnasta, nie znaną dotychczas kombinację liter. Jednocześnie postępowanie poety traktować można nie tyle jako odkrycie sekretu i pochodną mistycznego doświadczenia, ile jako bluźnierstwo przeciwko Bogu. Ów konceptualizowany za pomocą określeń „Nikt” czy „Nic” Stwórca nie pozwala już na odszyfrowanie swojego najgłębszego sensu, obnażenie prawdy zawartej w Imieniu. Bogu Celana odebrane bowiem zostało Jego miano; jeśli On powraca w wierszach, przywołany jest przez nazwy p u s te, pozbawione jakiegokolwiek desygnatu. Pozorne nawiązanie do kabalistycznego konceptu En-Sof (Boga jako Nicości) może okazać się w przypadku Celana jedynie kolejnym przejawem buntu - próbując złamać pieczęć tajemnicy, poeta ujawnia, że w miejscu, w którym spodziewamy się napotkać absolutny sens, czeka na nas wyłącznie bełkot ${ }^{44}$.

Polscy tłumacze wiersza starają się wszakże pokazać, iż druga wersja znikającej zagadki - niemieckie "Iefimnee” - nie musi być wcale pozbawiona znaczenia. Przybylak przekłada je jako „Ityśnie”, Krynicki zaś jako „Iawśnie” - obaj odsyłaja więc do przestrzeni onirycznej, zanurzenia we śnie. $Z$ punktu widzenia dykcji milczącej bardziej interesujące byłyby jednak dla czytelnika te litery, których już nie ma, które Celan wykreślił z pierwotnej kontaminacji. Tworzą one zbitkę spółgłoskową tsch, którą usłyszeć możemy w wielu niemieckich wyrazach; warto podkreślić, iż są to słowa w kontekście omawianej poezji wyjątkowo znaczące: „totschlagen” 'zabijać', ,totschweigen” 'przemilczać', a także „Tusche” 'tusz', „tuscheln” 'szeptać'. Wykluczenie dokonywane przez Celana przywodzi na myśl jeszcze jeden rzeczownik:

Por. z założeniami kabały profetycznej, która - poprzez kontemplację poszczególnych liter alfabetu hebrajskiego - prowadzi do odkrycia Boskiego Imienia. Zob. G. S c h ole m, Mistycyzm żydowski i jego główne kierunki. Przeł. I. Ka ni a. Warszawa 2007, s. 135-175.

44 W zupełnie innym kierunku zmierza Gadamerowska interpretacja twórczości Celana (H.-G. G ad a m e r, Kim jestem Ja i kim jesteś Ty? Komentarz do cyklu wierszy Celana „Atemkristall”. W: Czy poeci umilkną? Wybór, oprac. J. Margański. Przeł. M. Łukasiewicz. Przekł. przejrzał i wstępem poprzedził K. Bartoszyński. Bydgoszcz 1998) oraz propozycja Felstinera (op. cit.), który swój wywód o Keine Sandkunst mehr... kończy stwierdzeniem o dotarciu poety do esencji słowa i odsłonięciu jego ostatecznego sensu: „Nie ma już sztuki piaskowej, jest tylko sztuka śnieżna, ściśnięta przez własne okowy. Zostały tylko samogłoski, serce słowa, jego warunek sine qua non. Gdyby ten wiersz przetłumaczyć na hebrajski, w którym nie zapisuje się samogłosek, graniczyłby z ciszą, stałby się świadectwem dosłownej prawdy, której poszukiwał Celan” (s. 293). Interesujący punkt wyjścia (hebrajski przekład, który stałby się milczeniem) prowadzi Felstinera do przyjęcia pierwszej sugerowanej przeze mnie ewentualności - odkrycia Imienia, samej rzeczy. Zapomina on jednak zupełnie o innej możliwości, w której redukcja słowa wiodąca do milczenia nie odkrywa prawdy, ale pozostawia czytelnika w ciszy pozbawionej znaczeń. 
„Tisch” 'stół’, w niemczyźnie występujący m.in. w związku wyrazowym „Tisch des Herrn”, czyli ‘stół Pański’. Brakujący przedmiot można więc potraktować jako nie istniejące już miejsce spotkania. Jeżeli przywołamy kontekst religijny, w którym „stół Pański” oznacza sakrament Eucharystii, okaże się, że wykreślane przez poetę litery są także odcięciem się od możliwości porozumienia czy też nawiązania jakiegokolwiek kontaktu z Bogiem. Zmierzanie ku milczeniu przestaje zatem być drogą do prawdy (choć taka interpretacja mogłaby się utrzymać, szczególnie jeśli uruchomimy kontekst Rozmowy w górach), a staje się schodzeniem w mrok bez pocieszenia, w traumę nienazywalnego.

Obie ścieżki interpretacyjne wydają się słuszne - zarówno ta skoncentrowana na skreślonym, jak i ta zogniskowana wokół samego aktu wymazywania. Razem tworzą one pewnego rodzaju nierozstrzygalnik: figurę polegająca na paradoksalnym zderzeniu. Ich tajemnica pozostaje bowiem niema lub wcale nie istnieje. Kończące utwór samogłoski mogą być albo głosem Boga, albo bełkotem. Clou interpretacji negatywnej nie polega wszakże na tym, aby wybrać jedna z dróg lub aby odrzucić obie, ale raczej na tym, by pozbawić badacza obowiązku rozwiązania owej dialektyki. Trwając w jej nieafirmatywnym momencie ${ }^{45}$, balansując na granicy między teza a antyteza, udaje się uchwycić nietożsamość samego tekstu. Jak zauważa Helmut Böttiger w eseju Paul Celan. Miasta i miejsca:

Proces ten [tj. proces lektury] nie ma tu stanowić prostoliniowego kontinuum ani proponować powierzchownych czytelniczych utożsamień, lecz powinien, jak rozmowa, być rozpoczynaniem stale na nowo, ciagłym nawiązywaniem do dialogowego wątku ${ }^{46}$.

Wiersz musi pozostać „nierozwiązany”: wymaga od odbiorcy nie tylko zaakceptowania wielości jego interpretacji, ale też nieustannego podkreślania niewłaściwości każdej z nich oraz rozpoczynania procesu czytania wciąż od nowa. Wizja Böttigera jest hermeneutyczna; pragnie on odnaleźć ukryte miejsce spotkania, w którym wiersz będzie w stanie wreszcie udostępnić swoja prawdę ${ }^{47}$. Gdyby jednak zradykalizować postulat badacza, gdyby faktycznie ciągle od nowa podejmować lekturę Celanowskiego utworu, wydobywając $z$ niego głównie paradoksy, rozchodzące się we wszystkie strony możliwości i znaczenia, gdyby nie tyle czytać, ile szkicować mape ścieżek, na jakie poeta wchodzi, lecz ich ani nie potwierdza, ani nie falsyfikuje, wówczas ewentualnie udałoby się pokazać, na czym polega strategia nierozstrzygalnika $^{48}$.

Niemożność udzielenia odpowiedzi na pytanie o znaczenie wersu „i- $i-e$,

Zob. Th. W. Ad or n o, Dialektyka negatywna. Przekł., wstęp K. Kr ze mi e ni ow a, przy współpr. S. Krzemienia-Ojaka. Warszawa 1986, s. 587-588.

Böttiger, op. cit., s. 123.

Ibidem, s. 118.

Podobny sposób czytania Celana podejmuje Lipszyc (op. cit., s. 284), kiedy analizuje wiersz Ucieśnienie (Engführung): „I choć w tej notatce z lektury chcę sobie to i owo uporządkować, nie będę też na siłę dążył do nadmiernej spójności - lepiej chyba wskazać kilka nawet rozbieżnych ścieżek niż jakąś możliwość przegapić”. Strategia Lipszyca - rozpisywanie wiersza, a nie jego zinterpretowanie - pozwala wychwycić równolegle rozwijające się znaczenia tekstu, które często wzajemnie się znoszą, i nie zakłada konieczności odnalezienia dla nich syntezy. Wydaje mi się najlepszą metodą czytania praktyk dykcji milczącej. 
niemożność wybrania jednej z interpretacyjnych dróg wynika bowiem przede wszystkim $\mathrm{z}$ nadania pojedynczej literze zupełnie asemantycznego charakteru. Coraz dalej posunięty proces „destylacji języka” każe umieścić lirykę Celana po stronie ciszy, która nie konotuje niczego: jest negatywnym znakiem.

U Weberna przebieg desemantyzacji ma równie radykalny charakter. Kompozytor dąży do zupełnego rozbicia tradycyjnych struktur harmonicznych (i - tym samym - przyzwyczajeń odbiorczych) poprzez d ow a r toś c i ow a n ie dy s o na n$\mathrm{s} \mathrm{u}^{49}$. W pieśniach $\mathrm{z}$ op. 25 widać to szczególnie w partii fortepianowej. W pieśni III Webern używa właściwie tylko dysonującego akordu septymy wielkiej (trójdźwięki mają wymiennie budowę $3+8$ lub $5+6$ ); utwór otwiera odległość septymy, po której następuje akord złożony z kwarty i trytonu - uchodzącego w tradycji za diabolus in musica: najbardziej fałszywy interwał. Stosunkowo spokojna melodia głosu, charakteryzująca się małym ambitusem i jednostajnym rytmem, jest więc nieustannie atakowana przez dysonansowy akompaniament akordowy. Dodatkowo sugestia kompozytora, by całość wykonywać sehr rasch (bardzo szybko), wzmaga wrażenie gwałtowności i nieprzystawalności partii wokalnej oraz instrumentalnej.

Dysonans Webernowski rozbija więc po raz kolejny relacje między muzyką a tekstem, jednak nie to wydaje się jego najważniejszą funkcją. Idea utworu pozbawionego muzycznej składni, przebiegu muzycznego warunkowanego systemem harmonicznym, uderza przede wszystkim w przyzwyczajenia odbiorcze. Słuchacz zostaje skonfrontowany z niezrozumiałym układem dźwięków, w którym współbrzmienie nie rozwiązuje się w sposób tradycyjny, czyli konsonansowo. Oczywiście, ekspansja dysonansu rozpoczyna się wcześniej: romantyczne eksperymenty Ferenca Liszta, a następnie atonalne próby Richarda Wagnera czy Claude’a Debussy'ego wprowadzaja powoli odbiorcę w przestrzeń muzyki nie znajdującej rozstrzygnięcia w tonice. Dodekafonia Schönberga idzie wszakże krok dalej - proponuje bowiem inną zasadę porządkującą, która opiera się na myśleniu liczbowym, a nie brzmieniowym. Jak słusznie podkreśla Kathryn Bailey w monografii muzyki Weberna, dodekafonia przeciwstawia muzyce - technikę. Przyzwyczajenia ucha nie maja już żadnego znaczenia. Autor Trzech pieśni radykalizuje jednak jeszcze bardziej ideę swojego nauczyciela. O ile bowiem Schönberg nigdy nie zrezygnował w muzyce Z wyrazowości, ekspresywności (co najlepiej obrazują jego utwory religijne: Mojżesz i Aaron, Ocalały z Warszawy op. 46, Psalm Wspótczesny op. 50c), o tyle Webern dążył do jej coraz większego rozproszenia i ostatecznie zaniku. Dysonans ciagle zaskakuje słuchacza dziwnością artefaktu, który nie znajduje żadnego końca ani ce w istocie do jego zniesienia (według koncepcji muzyki dodekafonicznej nie istnieje opozycja dysonansu i konsonansu, gdyż wszystkie współbrzmienia są równorzędne), nadal pozostaje nieprzyjemne i brzmi fałszywie. Jak pisze M. Gołąb (Muzyczna moderna $w$ XX wieku. Między kontynuacja, nowością a zmiana fonosystemu. Wrocław 2011, s. 200): „będący w dyspozycji kompozytora materiał dwunastu dźwięków skali chromatycznej nie pociągał już za sobą konieczności ani strukturowania go w trój-, cztero- i wielodźwięki według klasyfikacyjnej zasady konsonansu i dysonansu, ani łączenia tak ukształtowanych akordów wedle norm harmonii funkcyjnej”. Jednocześnie - wciąż budził opór publiczności i środowiska muzycznego jako niezrozumiały i pozbawiony muzycznego sensu. 
początku, wydaje się wyrwany z ciszy, zawieszony w punkcie wyjścia (dwa finalne akordy op. 25, o budowie $3+8$, niejako się dublują, coraz mocniej wtapiając się w milczenie pozamuzyczne: dynamika zmierza od piano do pianissimo). Dysonans stanowi więc ideę wyjściową dla stworzenia muzycznego p un k tua li z mu. Twórczość Weberna zaprzecza tym samym wizji muzyki jako opowieści, mającej własną dramaturgię, akcję. Dźwięk zostaje przez niego zawieszony w próżni milczenia, styka się $z$ innymi pojedynczymi nutami, które nie wynikają $z$ siebie i nie wchodzą w relacje przyczynowo-skutkowe. Jak zauważa słusznie Zbigniew Skowron:

Jedyną rzeczywistość muzyczną stanowią w dziełach Weberna konstelacje fenomenów dźwiękowych wzajemnie od siebie niezależnych, a ekspresja znajduje swe źródło w sile oddziaływania dźwięku punktu. Podążając inną drogą dociera Webern do tego samego celu, który osiagną̧ już wcześniej Varèse: do koncepcji muzyki jako czysto fizycznej struktury dźwiękowej, uwolnionej od symbolicznych zależności i przeciwstawionej jedynie ciszy ${ }^{50}$.

Dźwięki istnieją tu niejako zawieszone w swoim brzmieniu i jeśli oddziałują, to tylko wertykalnie - kreując nowe, nieoczekiwane współbrzmienia. Ich układ horyzontalny nie służy zaś rozwojowi motywów muzycznych, ale tworzeniu swoistej gry odbić. Nuty traca punkt odniesienia, zostają skazane na wchodzenie w nieustabilizowane relacje wyłącznie między sobą. Lustrzane konstrukcje Weberna wykorzystują cisze jako tło dla owej gry (bez)znaczeń - pauzy służą odizolowaniu poszczególnych nut od siebie, nadaniu im autonomii i wyrwaniu ich z kontekstu. Webern nie tylko więc dąży w muzyce do antywyrazowego, „czystego” traktowania dźwięku, ale skupia się także na ograniczeniu jego możliwości dynamicznych. Kontrasty pomiędzy natężeniami nie interesują autora Trzech pieśni - w przeciwieństwie do Schönberga czy Berga. Webern buduje swój muzyczny mikroświat z dźwięków najcichszych, zanikających, trudnych do wysłyszenia. Jego utwory wymagają absolutnej ciszy w odbiorze - tylko ona pozwala im wybrzmieć.

Cisza wiazże się dla Weberna $z$ próbami dotarcia do sedna muzyki, odkrycia jej tajemnicy. Dźwięk musi zostać zastapiony milczeniem, gdyż to w nim właśnie tkwi sens - ono przekazuje więcej niż narracja, melodia. Nie dziwi zatem przywoływany przez Stawowy postulat Weberna, pochodzacy z rozmów z Peterem Stadlenem, aby dostrzec w Wariacjach „nie pojedyncze dźwięki, jakie napisał, ale całe kaskady dźwięków" 51 - owe kaskady istnieją bowiem w pauzie, w wewnątrzmuzycznej ciszy. Są najgłębszym wyrazem tego, co nie może być zawarte w realnym dźwięku, muszą pozostać zawieszone w wyobrażeniu. Cały potencjał myślowy (choć także ekspresywny) muzyki Weberna kryje się właśnie w tym, co przemilczane i nie istniejące.

Punktualizm jest więc najdalej idącym skutkiem poetyki muzycznej polegającej na ograniczeniu artykulacji, skupieniu na pauzie oraz eksploracji dynamiki piano ${ }^{52}$. Można wręcz zaryzykować twierdzenie, iż stanowi on odpowiednik Celanowskiej

Z. S k ow r o n, Teoria i estetyka awangardy muzycznej drugiej połowy XX wieku. Warszawa 1989, s. 35-36.

St aw owy, op. cit., s. 181.

S t a w o wy (ibidem) przywołuje następującą anegdotę o pianiście, który pracował z Webernem nad wykonaniem Wariacji fortepianowych: „A już zupełnie bezradny stanął [...] Stadlen wobec żądań Weberna w dziedzinie pianissima (obsesja Weberna, która doprowadziła do tego, że jeden $z$ dowcipnych adwersarzy puścił plotkę, jakoby Webern wymyślił [...] określenie pensato- pomyślane)”. 
fragmentacji wyrazów - mikrostruktury liryczne, niemożliwe do umiejscowienia $\mathrm{w}$ domenie muzyki, znalazłyby tym samym pewne odzwierciedlenie w jej obrębie. Webern rozbija bowiem język muzyczny ${ }^{53}$; podobnie jak Celan - demistyfikuje go, pokazując, że utrwalone przez tradycje współbrzmienia są tylko konwencjonalna mowa instytucji. Muzyka zaś ma za zadanie podążać za zmieniającym się historycznie doświadczeniem i rozwijać swoje zaplecze konceptualne oraz techniczne ${ }^{54}$. Tam, gdzie poeta stara się wyodrębnić nieznaczącą pojedynczość litery, obnażyć jej niemote - Webern ofiarowuje słuchaczowi punctum: dźwięk zdany sam na siebie, oczekujący dopiero na włączenie go w większą strukturę.

Dykcja milcząca, nad którą pracuja - można powiedzieć, że wspólnie - Celan i Webern, nieustannie jednak ucieka przed ową Całością, gdzie każde słowo i każda nuta odnajdą swoje miejsca znaczące. Głębokie przemyślenie przez nich wszelkich elementów dzieła, kształtowanie go na podobieństwo hermetycznej zagadki czyni z niego rebus wciąż nie rozwiązany. O ile bowiem da się je technicznie przeanalizować i opisać, o tyle jego przesłanie zawsze pozostaje otoczone pewną tajemnicą: $w$ bezmowności, filozofii niemego przedmiotu kryje się nieusuwalny naddatek (bez)sensu, którego nie sposób przemilczeć.

\author{
Abstract \\ MICHALINA KMIECIK Jagiellonian University, Cracow
}

\title{
SILENT DICTION: CELAN AND WEBERN
}

The article focuses on stillness and silence as on the basic determinants of avant-garde negative aesthetics (defined in Theodor W. Adorno's view) and is limited to the analysis of the problem to the example of Paul Celan's Keine Sandkunst mehr... (No more sand art...) and Anton Webern's Drei Lieder (Three Songs) Op. 25. The starting point is a reflection over the structural presence of silence in a literary and musical work. Referring to researchers' assumptions (mainly to Piotr Śniedziewski's analyses) about the role and methods of introducing silence to a work of art, manifestations of "silent diction" are indicated: breaking and disappearing of words, resignation from expressive musical narration, concentration on a single autonomised letter or sound, demise of syntax, and neutralising of meanings. Accumulation of silencing strategies proves to be one of the most vital features of Celan's and Webern's poetics and leads to composing a work of art in the likeness of an insoluble riddle.

W swoich wykładach W e b e r n (The Path to the Music, s. 16, 42-43) często zwracał uwagę na fakt, że muzyka niezaprzeczalnie jest językiem. 